$7^{\text {th }}$ Asia-Pacific International Conference on Environment-Behaviour Studies, St Leonard Hall, Edinburgh University, United Kingdom, 27-30 July 2016

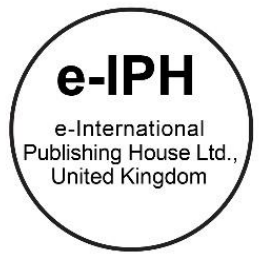

\title{
Competency Framework for the Property Management Industry
}

\author{
Zarita Ahmad Baharum * ${ }^{*}$, Ting Kien Hwa ${ }^{2}$, Sharuzaman Mohd Salleh ${ }^{3}$ \\ ${ }^{1}$ Centre for Real Estate Research, Faculty of Architecture, Planning \& Surveying, Universiti Teknologi MARA, Malaysia
}

\begin{abstract}
Property management is a very complex and challenging $24 / 7$ profession and the team consists of various backgrounds to ensure that it can cater to the needs and requirements of each building. Thus, to deliver quality services would require a minimum competency framework according to their scope and area of work. This research is aim to develop the property management competency framework that is applicable to the property management service delivery in Malaysia. The procedures used in developing this framework consists of five stages namely literature review, data collection, focus group discussion (national and international), and verification and validating the proposed competency framework with Industry Expert Panels. Findings reveal that the Competency Framework consists of three levels namely foundational, expert area and added competencies.
\end{abstract}

(c) 2016. The Authors. Published for AMER ABRA by e-International Publishing House, Ltd., UK. This is an open access article under the CC BYNC-ND license (http://creativecommons.org/licenses/by-nc-nd/4.0/).

Peer-review under responsibility of AMER (Association of Malaysian Environment-Behaviour Researchers), ABRA (Association of Behavioural Researchers on Asians) and cE-Bs (Centre for Environment-Behaviour Studies), Faculty of Architecture, Planning \& Surveying, Universiti Teknologi MARA, Malaysia.

Keywords: Property management, competency framework, property management industry

\section{Introduction}

Property management in Malaysia is a profession regulated under the Valuers, Appraisers, and Estate Agent Act 1981. The Board of Valuers, Appraisers and Estate Agents is responsible to ensure that the real estate professionals abide by the rules and guidelines as well as to strengthen the professional integrity and ethics. Hence to achieve this, a formulation of competency framework for the property management team will be very valuable and beneficial to the industry and the stakeholders.

The competency standards will enhance the industry's overall professionalism and competitiveness by developing and setting the competency requirements for each level of property management services required by the building and property industry. This will act as benchmarks for the skills required in performing different job functions of the industry including industry specific knowledge, professional skills and soft skills etc. Professional bodies in the property management industry include Board of Valuers, Appraisers and Estate Agents, Malaysia

\footnotetext{
* Corresponding author. Tel.: +0-000-000-0000

E-mail address: zarit928@salam.uitm.edu.my
}

2398-4287 @ 2016. The Authors. Published for AMER ABRA by e-International Publishing House, Ltd., UK. This is an open access article under the CC BY-NC-ND license (http://creativecommons.org/licenses/by-nc-nd/4.0/).

Peer-review under responsibility of AMER (Association of Malaysian Environment-Behaviour Researchers), ABRA (Association of Behavioural Researchers on Asians) and CE-Bs (Centre for Environment-Behaviour Studies), Faculty of Architecture, Planning \& Surveying, Universiti Teknologi MARA, Malaysia.

DOI: http://dx.doi.org/10.21834/e-bpj.v1i4.114 
(BoVAEA), Royal Institution of Surveyors Malaysia (RISM), Association of Valuers, Property Managers, Estate Agents, and Property Consultants in Private Sector, Malaysia (PEPS), and the Malaysian Institute of Professional Property Managers (MIPPM).

\section{Background of the Study}

Property management seeks to advice on the establishment of an appropriate framework within which to oversee property holdings to achieve the agreed short- and long-term objectives of the estate owner and particularly to have regard to the purpose for which the estate is held (Scarrett,1983). The basic needs will be to carry out such tasks as negotiating rental on suitable terms, initiating and negotiating rent reviews and lease renewals, overseeing physical maintenance and the enforcement of lease covenants. These activities will take place within an agreed strategic framework where there is a need to be mindful of the necessity of upgrading and merging interests where possible, recognising other opportunities for the development of potential and fulfilling owner's legal and social duties to the community.

The Valuers, Appraisers and Estate Agents Act 1981 (Act 242), describe property management as the management and control of land, building and any interest therein. There are various perspectives on the definitions of property management namely from the statutes/legislations, the property councils, the professional bodies and the academia. Nonetheless all these definitions have the same theme of managing a property which involves establishing goals and objectives, implementing policies, monitoring and reviewing strategies to the benefit of the owner, tenants as well as enhancing the value of the property.

\section{Functions of Property Management}

Property management functions can be divided into four clusters, namely: administrative (Shardy, Arman, \& Abd Hamid, 2011; Zaiton, 2007; Kyle, Baird, \& Spodek, 2000), marketing (Zaiton, 2007; Kyle, Baird, \& Spodek, 2000), investment/finance and physical management (Shardy, Arman, \& Abd Hamid, 2011; Zaiton, 2007; Kyle, Baird, \& Spodek, 2000). This is supported by the Valuers, Appraisers and Estate Agents Act 1981 (Act 242), where property management responsibilities include the following:

a) Monitoring outgoings for the property and making payments out of the income from the property;

b) Preparing budgets and maintaining financial records of the property;

c) Enforcing the terms of leases and other agreements pertaining to the property;

d) Advising on sale and purchases decisions;

e) Advising on insurance matters;

f) Advising on the opportunities for the realisation of development or investment potential of the property; and

g) Advising on the necessity for upgrading the property or for the merging of interests.

Additionally, the Malaysian Property Management Standards covers the following functions:

(a) Building management

(b) Maintenance management

(c) Financial management

(d) Administrative management

(e) Insurance management

(f) Tenancy and lease management

Further to this, the practice of residential property management involves the following activities (Institute of Residential Property Management, 2012):

(a) Setting up management agreements

(b) Setting up and carrying out management services 
(c) Managing service charges and associated finances for property management

(d) Facilitate the maintenance of managed properties

(e) Manage service providers

(f) Implement and monitor health and safety controls for managed properties

(g) Manage effective relationships with customers and other parties

(h) Manage effective use of information and communication links

(i) Manage and respond to problems relating to managed properties

Table 1 below summarises the matrix of property management functions from the various literatures. Currently, albeit guidelines and legislations available on this matter, property management practice is based on the management's own guideline and standard (Tiun, 2009). Tiun (2009) added that property management and maintenance standard of management service provided by most of the property managers and developers are questionable. Perhaps the main drawback in this issue is the lack of a structured process for property performance measurement (Kishk, 2005). But this paper argues that a competency-based framework in the property managment could be the solution the profession needed.

Table 1: Matrix of Property Management Functions

\begin{tabular}{|c|c|c|c|c|}
\hline & Function & $\begin{array}{c}\text { BOVEA } \\
\text { (1991) }\end{array}$ & $\begin{array}{c}\text { Malaysian } \\
\text { Property } \\
\text { Management } \\
\text { Standard }\end{array}$ & $\begin{array}{c}\text { Institute of } \\
\text { Residential } \\
\text { Management } \\
\text { (2012) }\end{array}$ \\
\hline 1 & $\begin{array}{l}\text { Monitoring outgoings for the property and making payments out of the } \\
\text { income from the property }\end{array}$ & $\bar{x}$ & $\bar{x}$ & $\bar{x}$ \\
\hline 2 & Preparing budgets and maintaining financial records of the property & $x$ & $x$ & \\
\hline 3 & $\begin{array}{l}\text { Enforcing the terms of leases and other agreements pertaining to the } \\
\text { property }\end{array}$ & $\mathrm{x}$ & $\mathrm{x}$ & \\
\hline 4 & Advising on sale and purchases decisions & $x$ & & \\
\hline 5 & Advising on insurance matters & $x$ & $x$ & \\
\hline 6 & $\begin{array}{l}\text { Advising on the opportunities for the realisation of development or } \\
\text { investment potential of the property }\end{array}$ & $x$ & & \\
\hline 7 & $\begin{array}{l}\text { Advising on the necessity for upgrading the property or for the merging of } \\
\text { interests }\end{array}$ & $x$ & $x$ & \\
\hline 8 & Health, safety and emergency management & & $x$ & $x$ \\
\hline 9 & Facilitate the maintenance of managed properties & & & $\mathrm{x}$ \\
\hline 10 & Manage effective relationships with customers and other parties & & & $x$ \\
\hline 11 & Manage effective use of information and communication links & & & $\mathrm{x}$ \\
\hline 12 & Manage and respond to problems relating to managed properties & & & $\mathrm{x}$ \\
\hline
\end{tabular}

General property management involves the legal, technical, physical, operational and financial control of a property by a landlord, tenant of other party having an interest in that property and/or their agents in the pursuit of their needs and their obligations. In summary, the functions of property management are summarised in Table 2 below. 
Table 2: The functions of property management

\begin{tabular}{ll}
\hline \multicolumn{1}{c}{ Function } & \multicolumn{1}{c}{ Scope } \\
\hline Administrative & $\begin{array}{l}\text { This operation part of property management requires constant monitoring outgoings, income, and expenditure from the } \\
\text { property. Legal contractual enforcement of the term of leases and other agreements pertaining to the property is also } \\
\text { expected. }\end{array}$ \\
In addition to advising on the sale, purchase and leasing matter, the property management personnel is also required \\
to formulate and execute necessary marketing programs as well as promotions and other advertising strategies, when \\
deem appropriate. The objective of these plans must be to achieve or assist in increasing the occupancy rate or sales. \\
The property management team is considered as the representative of the property owner in realising an optimum \\
return on his / her investment, acting as the owner's consultant whenever property investment opportunity arises. Thus, \\
it is imperative that proper budgeting and financial records are maintained. \\
This physical function of property management often referred to as facility management. In addition, monitoring the \\
quality and functionality of the property structures, assets, and common areas; the property management personnel is \\
also expected to keep a good relationship with vendors and contractors to ensure quality work will be produced in a \\
timely manner. They are also required to advise the property owner on the necessity for upgrading the property or for \\
the merging of interests, whenever needed.
\end{tabular}

\section{Justification of the research}

To date there is no competency guideline available for the property management industry, thus, this has caused complaints amongst the stakeholders in regards to the quality and the team that managed the building. This research is funded by the NAPREC Research Grant - NAPREC (R\&D). The research aims to enhance the service delivery of the property management services by developing a competency framework for property management profession.

\section{Competency and Competency Framework}

Competency is defined as a person-related concept that refers to the dimensions of behavior lying behind the competent performer. In addition, competence is a work-related concept that refers to areas of work at which the person is competent; and competencies are often referred as the combination of the above two. There are five types of competencies namely:

a) Foundation competencies are the behaviours, skills and knowledge that are shared by everyone in the organisation, e.g. communication.

b) Focus competencies are those related to a particular industry or profession, e.g. legislation or best practice guidelines.

c) Execution competencies are those required to carry out a specific role or level, e.g. customer service agent or customer service manager.

d) Potential competencies are those that the organisation would like to see an individual develop for the benefit of the organisation. At this stage, it is also important to encourage an individual to consider their personal potential competencies as well as those imposed by the organisation.

e) Aspiration competencies are those that an individual hopes to develop over a longer period and need not be connected to an organisational need either current or in the future. 
Competency plays an important role in any organization nationwide. The benefits of competencies include recruit the right people through a cost effective, consistent, fair and open process; deploy and maintain the right people in the right jobs; assess performance against a well-defined set of behaviours, skills and knowledge; retain the right people by developing them in the right way and linking competence to organisational performance; reward the right people appropriately through measurable competencies linked to personal/organisational performance; and manage workforce and succession planning in an objective manner.

Competencies framework is defined as the successful performance in specific jobs, job groups, organizations, occupations, or industries and are the foundation for recruitment and hiring, training and development, and performance management. Industry-wide framework captures the broad baseline skills and competencies common to an entire industry rather than just an industry sector or occupation. Various studies have covered the competencies framework which includes both the public sector and private sector.

\section{Methodology}

This research focus on the property management (operational) of residential properties. The research procedures are divided into five stages. Stage 1 is the review of secondary information/data based on literature review - the focus is on the functions of property management and to identify the various types of critical jobs and specifications relating to property management. Stage 2 is the data collection on job specifications. This is based on the sampling of job descriptions, organization charts, law/regulatory materials as well as the professional practice guides and standards. Stage 3 is to identify the competency framework by reviewing job descriptions, existing framework developed by other international bodies and focus groups from Industry Expert Panels (nationally and internationally) to identify the knowledge skills and abilities required to perform each duty. Stage 4 involves the analysis based on the collected data and focus towards creating competency categories based on the above evaluation and mapping the competencies against the main job profiles. Stage 5 is the verification and validating the proposed competency framework with Industry Expert Panels.

\section{The Findings}

The development of the conceptual framework has gone through an extensive literature search (USA, 2010; UK, 2011; Irish, 2002; JKR, 2006; BIFM, RICS, HK). Table 3 summarise the category and elements of competencies from various literature.

Table 3: Matrix of Competencies by Category and Elements (various authors)

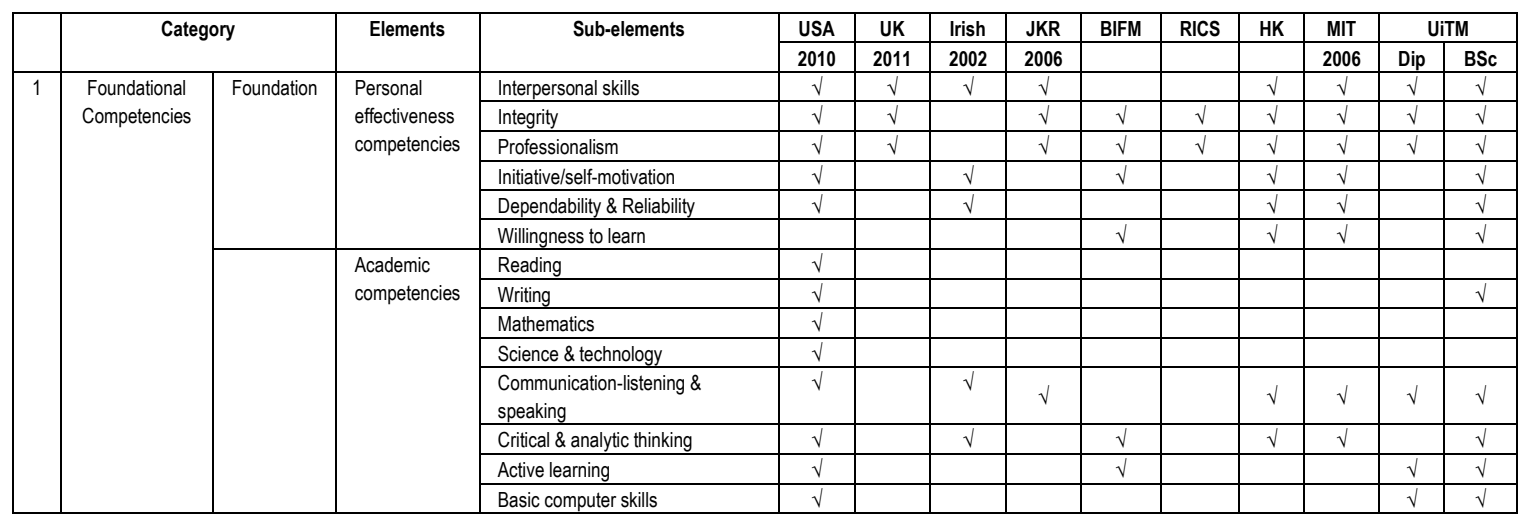




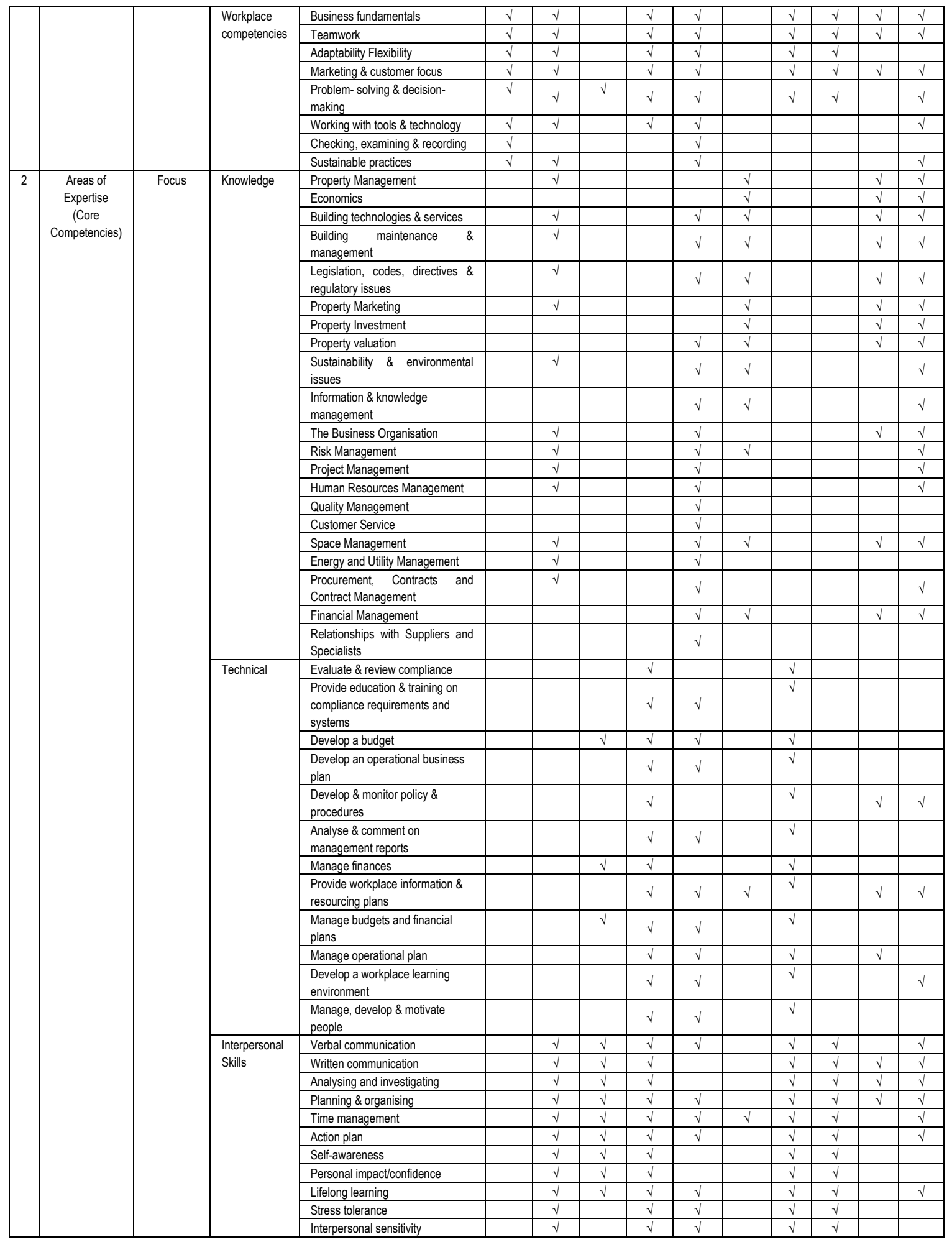




\begin{tabular}{|c|c|c|c|c|c|c|c|c|c|c|c|}
\hline \multirow[t]{6}{*}{3} & \multirow{6}{*}{$\begin{array}{l}\text { Added Values: } \\
\text { Leadership } \\
\text { Managerial } \\
\text { Competencies }\end{array}$} & \multirow{6}{*}{$\begin{array}{l}\text { Successful } \\
\text { Execution }\end{array}$} & Leadership & $\sqrt{ }$ & $\checkmark$ & $\checkmark$ & $\checkmark$ & $\sqrt{ }$ & $\checkmark$ & $\sqrt{ }$ & \\
\hline & & & Vision & $\sqrt{ }$ & $\sqrt{ }$ & $\sqrt{ }$ & $\sqrt{ }$ & $\sqrt{ }$ & $\sqrt{ }$ & $\sqrt{ }$ & $\sqrt{ }$ \\
\hline & & & $\begin{array}{l}\text { Empowering } \\
\text { others }\end{array}$ & $\checkmark$ & $\checkmark$ & $\sqrt{ }$ & $\checkmark$ & $\sqrt{ }$ & $\sqrt{ }$ & $\checkmark$ & $\checkmark$ \\
\hline & & & Building trust & $\sqrt{ }$ & $\sqrt{ }$ & $\checkmark$ & $\sqrt{ }$ & $\sqrt{ }$ & $\sqrt{ }$ & $\sqrt{ }$ & \\
\hline & & & $\begin{array}{l}\text { Managing } \\
\text { performance }\end{array}$ & $\sqrt{ }$ & $v$ & $\checkmark$ & $\checkmark$ & $\checkmark$ & $\sqrt{ }$ & $\checkmark$ & \\
\hline & & & $\begin{array}{l}\text { Judgement/ } \\
\text { decision- } \\
\text { making }\end{array}$ & $\checkmark$ & $\sqrt{ }$ & $\checkmark$ & $\checkmark$ & $\checkmark$ & $\sqrt{ }$ & $\checkmark$ & $\checkmark$ \\
\hline
\end{tabular}

Further to this, a focus group discussion (1 ${ }^{\text {st }}$ stage) has been conducted. Table 4 below tabulates the total mean score for each of the categories. By category, leadership has the highest total mean score of 4.57 followed by Foundational competencies (4.20) and Areas of expertise competencies (4.17). This is rather interesting as the area of expertise is supposed to be the fundamental needed to equip a person prior to joining the industry but the weight given in the mean score demonstrates that it is not the priority. Based on the respondents' feedback it demonstrates that overall the respondents agreed that all the categories, elements, and items in the framework are important, however, due to the priority or weight based on the Likert scale thus producing the various mean score for the items.

Table 4: Total mean score for the different competencies categories

\begin{tabular}{|c|c|c|c|c|c|c|}
\hline & \multicolumn{2}{|l|}{ Category } & Elements & \multicolumn{2}{|c|}{ Total Mean score } & Ranking \\
\hline \multirow[t]{3}{*}{1} & \multirow{3}{*}{$\begin{array}{l}\text { Foundational } \\
\text { Competencies }\end{array}$} & \multirow[t]{3}{*}{ Foundation } & Personal effectiveness competencies & 4.31 & \multirow{3}{*}{4.20} & \multirow{3}{*}{2} \\
\hline & & & Academic competencies & 4.08 & & \\
\hline & & & Workplace competencies & 4.22 & & \\
\hline \multirow[t]{3}{*}{2} & \multirow{3}{*}{$\begin{array}{l}\text { Areas of Expertise } \\
\text { (Core Competencies) }\end{array}$} & \multirow[t]{3}{*}{ Focus } & Knowledge & 4.09 & \multirow{3}{*}{4.17} & \multirow{3}{*}{3} \\
\hline & & & Technical & 4.07 & & \\
\hline & & & Interpersonal Skills & 4.36 & & \\
\hline \multirow[t]{6}{*}{3} & \multirow{6}{*}{$\begin{array}{l}\text { Added Values: Leadership } \\
\text { Managerial Competencies }\end{array}$} & \multirow{6}{*}{$\begin{array}{l}\text { Successful } \\
\text { Execution }\end{array}$} & Leadership & & & \multirow{6}{*}{1} \\
\hline & & & Vision & & & \\
\hline & & & Empowering others & & 4.57 & \\
\hline & & & Building trust & & & \\
\hline & & & Managing performance & & & \\
\hline & & & Judgement/ decision- making & & & \\
\hline
\end{tabular}

The $2^{\text {nd }}$ focus group from various organizations including public and private and a discussion at the national and international level have been conducted and Fig. 1 illustrates the hierarchy of the Property Management Team. Findings, deliberations, and discussions from both the $1^{\text {st }}$ and $2^{\text {nd }}$ focus group have been the basis to develop a conceptual framework as in Fig. 2.

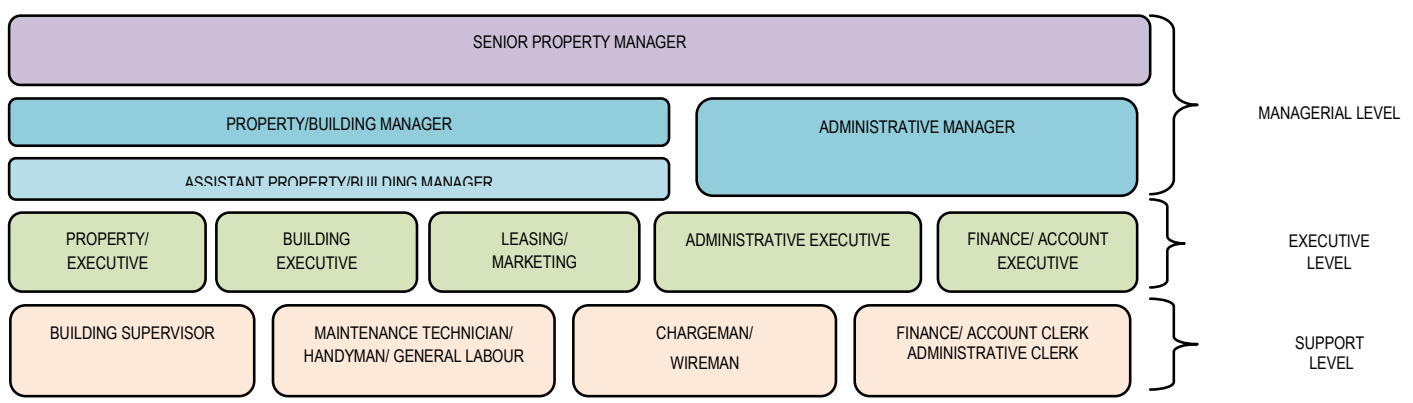

Fig .1: The Hierarchy of Property Management Team 
This framework identifies the hierarchy of the property management team according to three different tiers namely the managerial level, the executive level, and the support level. In each of the hierarchy, the framework has also established the designation, qualification, requirements, duties, and responsibilities. The scope of the competencies for each of the designation is developed under three integrated elements i.e. the Foundational Competencies, the Core Competencies and the Added Competencies. Each of the competency elements carries different requirements that are essential for the professional property manager and team members to deliver quality services to the clients, stakeholders, and industry.

The framework developed in this research is generic in nature and can be adopted according to the requirements and complexity of the property management organization. The basis of this framework is in accordance to:

i) Property Management Standards of the Board of Valuers, Appraisers and Estate Agents Malaysia

ii) Strata Management Act 2013

iii) Strata Management (Maintenance and Management) Regulations 2015

iv) Strata Title Act 1985

v) Public and Private Institutions Competencies Guidelines

vi) International Competencies Guidelines

Additionally, a pyramid of property management competencies (Fig. 3) has been formulated based on the above conceptual framework. Rationally the foundation will be the bottom layer followed by the areas of expertise and the top layer is the added values. This pyramid displays the essential elements that shape the property management competencies.

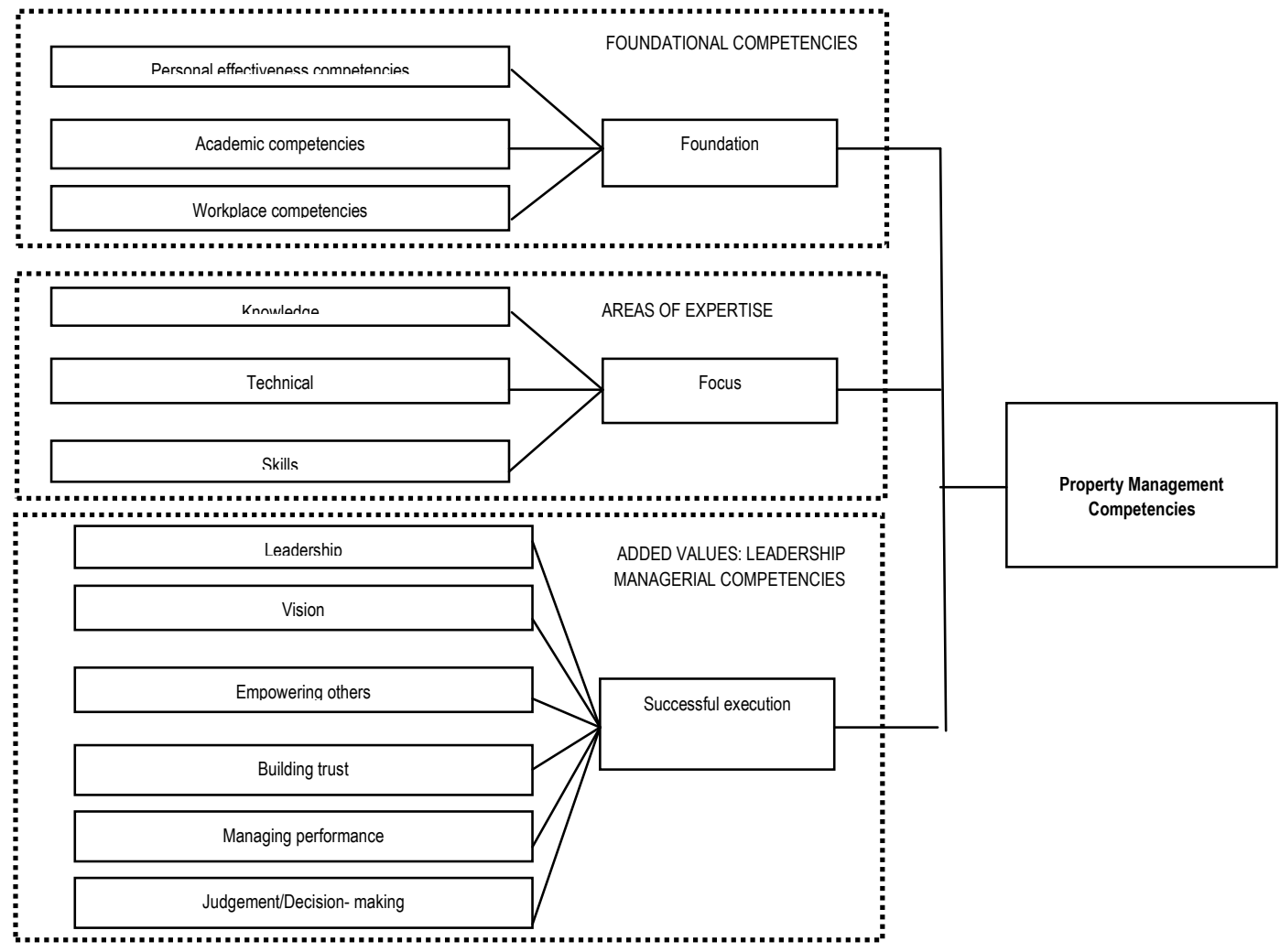

Fig. 2: A Conceptual Competency Framework for Property Management 


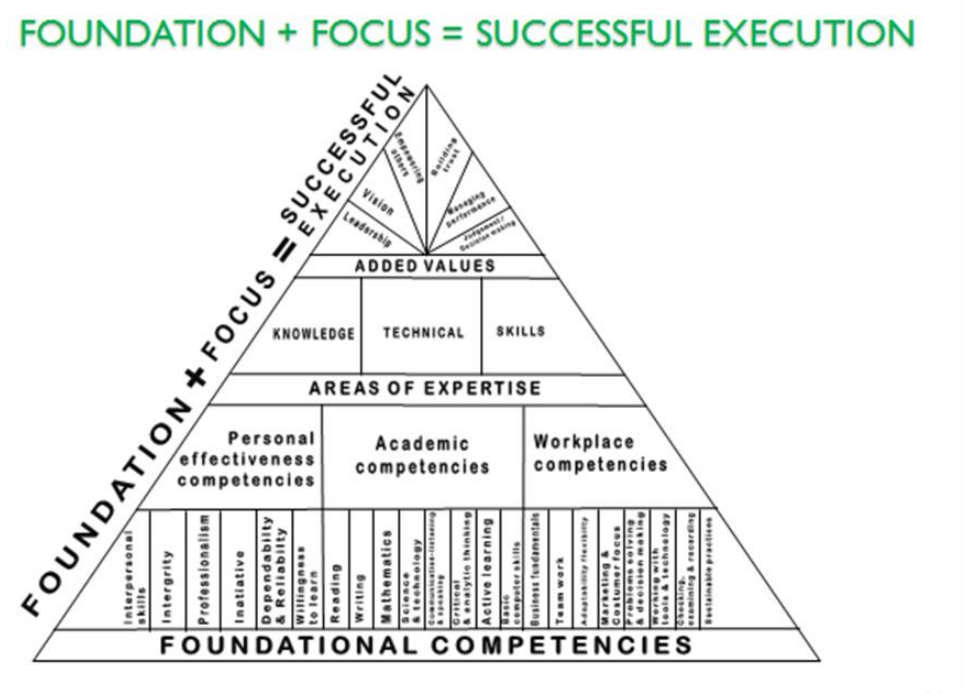

Fig 3: The Pyramid of Property Management Competencies

\section{Conclusions}

The rapid spread of globalisation, the growth of information technology and the emergence of sustainability agenda have dramatically changed the business environment in which the professional property managers operate. These led to a demand for more education and the need to develop a broader range of skills to succeed in the increasingly competitive and complex property management business environment. The property management professionals must change if it is to be relevant and add value to the property management profession and industry.

The knowledge base and technical skills required of today's property management professional have changed significantly. The competency requirements for a professional property manager include advanced technical knowledge, a good grasp of business operations and a working knowledge of the real estate business environment. The ability to integrate different business concepts, apply sustainability principles, to be cost effective and a strong ethical foundation are essential elements of a successful professional property manager. In response to these challenges, this research has focused on identifying the professional competencies expected of the various personnel in a property management team. The outcome of this research project is a Competency Framework for the Property Management Industry.

The Framework introduces a generic framework of competencies related to the property management professionals and supporting staff. It is made up of Foundational Competencies and Core Competencies which are essential competencies for any property management personnel. It is hoped that the Framework will provide the basis for future research that will investigate into detailed aspects of competencies related to the property management professionals.

\section{Acknowledgements}

We gratefully thanked the Valuation \& Property Services Dept (JPPH) and the National Institute of Valuation (INSPEN) for awarding the NAPREC Research Grant - NAPREC (R\&D) 8/12 - to enable this research project to be carried out. Special thanks to the contributions from representatives of the Professional Bodies, Institutions and Organisations (national and international) that have participated in this study. 


\section{References}

BIFM (2009) The Revised Competencies, BIFM, UK

BIFM (2012). BIFM: Frequently Asked Questions. Retrieved October 18, 2012, from British Institute of Facilities Management (BIFM): http://www.bifm.org.uk/bifm/help

Bristol, UK Part 2 : Guidance on using the 2012 IAM Competences Framework

Institute of Asset Management (2012) the IAM Competences Framework, Version 3.2,

International Valuation Standards Council (2010) Discussion paper: Definition of a

International Valuation Standards Council (2012) A Competency Framework for Professional

JKR (2007) Competency Model \& Dictionary, Jabatan Kerja Raya Malaysia

Kyle, R. C., Baird, F. M., \& Spodek, M. S. (2000). Property Management, 6th ed. Chicago: Real Estate Education Company.

Management Competence Framework V.4 February 2013 Professional Valuer, London, UK

Property Management Standards of the Board of Valuers, Appraisers and Estate Agents Malaysia

RICS (2006) Commercial Property Practice, RICS Professional Guidance, Global

RICS (2011) Alignment of professional, academic and industrial development needs for quantity surveyors: The post recession dynamics. RICS Research

RICS (2013) Real Estate Management, RICS Professional Guidance, Global

RICS. (2008). RICS Public Sector Asset Management Guidelines. Coventry: Royal Institution of Chartered Surveyors (RICS).

Scarrett, D. (1983). Property Management. New York: E. \& F. N. Spon.

Shardy, A., Arman, A. R., \& Abd Hamid, K. P. (2011). The characteristics of real estate assets management practice in the Malaysian Federal Government. Journal of Corporate Real Estate, 13(1), pp. 16 - 35.

Strata Management (Maintenance and Management) Regulations 2015

Strata Management Act 2013

Strata Title Act 1985

UK Civil Service. (2010, June). UK Government Property Unit: The Property Asset Management Competence Framework. Retrieved October 17, 2012, from UK Civil Service: http://www.civilservice.gov.uk/wp-content/uploads/2011/09/CompetenceFrameworkJune2010_tcm6-37792.pdf

UK Civil Service. (2012, June 19). UK Government Property Unit: Property Asset Management Profession Conference 2012. Retrieved October 25, 2012, from UK Civil Service: http://www.civilservice.gov.uk/wp-content/uploads/2012/07/A-Howarth-Presentation.pdf

UK Government (2012), Civil Service Competency Framework (2012-2017)

UK Government Civil Service Professional Skills and Capability (2013) Property Asset

Valuers, Appraisers, and Estate Agent Act 1981, Valuers, London, UK

Zaiton, A.(2007) Corporate real estate - Another real estate area. by Zaiton Ali. Retrieved October 1, 2012, from http://psasir.upm.edu.my/806/1/CORPORATE\%2520REAL\%2520ESTATE\%2520ANOTHER\%2520REAL\%2520ESTATE\%2520AREA.pdf 